\title{
Scleromyxedema without Paraproteinemia: Treatment with Thalidomide and Prednisolone
}

\author{
Sara Saniee Ghazaleh Davarnia \\ Department of Dermatology, Tabriz University of Medical Science, Tabriz, Iran
}

\section{Keywords}

Scleromyxedema $\cdot$ Paraproteinemia $\cdot$ Mucinoses $\cdot$ Thalidomide

\begin{abstract}
Scleromyxedema is a rare and distinctive variant of cutaneous mucinoses of unknown etiology. It is presenting with generalized papular eruption and sclerodermoid induration. Numerous treatment modalities have been reported to produce partial or permanent responses. This study reports on a case of scleromyxedema without paraproteinemia in a subject who experienced a partial response to thalidomide and prednisolone.

(C) 2016 The Author(s)

Published by S. Karger AG, Basel

\section{Introduction}

Scleromyxedema is a rare and distinctive variant of cutaneous mucinoses of unknown etiopathogenesis [1]. It is characterized by the formation of numerous lichenoid papules which coalesce to form generalized plaques that cause extensive thickening and hardening of the skin. There are two main divisions of lichen myxedematosus: (a) generalized papular and sclerodermoid form (scleromyxedema) with systemic, even lethal, manifestation, and (b) a localized form without a demonstrable paraprotein, which runs a more benign course [2]. Diagnostic criteria include generalized papules and sclerodermoid eruption, mucin de-
\end{abstract}


position and fibroblast proliferation, monoclonal gammopathy, and absence of thyroid disease [3].

Occasional patients with lichen myxedematosus have atypical features or features intermediate between scleromyxedema and localized lichen myxedematosus. This group includes patients with scleromyxedema who suffer from lack of monoclonal gammopathy as well as individuals with localized forms of lichen myxedematosus who also have a monoclonal gammopathy and/or systemic symptoms [4]. Possible treatment includes melphalan, interferon- $\alpha$, high-dose dexamethasone, autologous stem cell transplantation, thalidomide, cyclophosphamide, plasmapheresis, and intravenous immunoglobulin (IVIG) [5].

\section{Case Report}

A 41-year-old female patient presented with a 2-month history of pruritic lichenoid papules and tightening of the skin in her upper trunk, forehead, and arms. Glabella was involved with deep longitudinal furrows and folds (Fig. 1, Fig. 2, Fig. 3, Fig. 4). Pruritus and feeling of tightness in the skin were causing distress and impaired activity.

In addition, there were no internal manifestations. Histopathologic evaluation of a skin biopsy specimen revealed proliferation of fibroblasts, thickening collagen bundles with mucin deposition in the upper and mid dermis, and sparse perivascular infiltrate of lymphocyte in the upper dermis consistent with a diagnosis of scleromyxedema (Fig. 5).

The laboratory test results were in the normal range including complete blood cell count, levels of inflammatory parameters (erythrocyte sedimentation rate, C-reactive protein), electrolytes, calcium, glucose, antistreptolysin 0 , autoantibodies associated with scleroderma (anti-topoisomerase I and anti-centromeric antibodies), and thyroid function tests. Renal function tests and urine analysis were normal. Serum protein electrophoresis did not show polyclonal hypergammaglobulinemia and paraproteinemia. Immunofixation electrophoresis of serum and urine did not show monoclonal paraproteinemia. There was no evidence of hepatosplenomegaly in the ultrasound examination. Both the electromyogram and the nerve conduction velocity test results were normal, too. Chest radiograph and lung function tests showed no evidence of pulmonary involvement.

Given the lack of monoclonal gammopathy, we decided to begin treatment with thalidomide (initial dosage $100 \mathrm{mg} /$ daily) and prednisolone (30 mg/daily). Because of the patient's anxiety and distress, we added doxepin $(25 \mathrm{mg} /$ daily). Treatment with thalidomide continued for 3 months, and prednisolone was tapered within the treatment period. The patient exhibited remarkable improvement in symptoms such as pruritus and skin induration while skin lesions showed moderate response. During the treatment, the patient did not show signs of drug-induced neuropathy. The patient refused to continue the treatment due to remarkable improvement of the symptoms. Her 2-month follow-up exam showed no progression of the signs and symptoms.

\section{Discussion}

Scleromyxedema is a chronic and progressive disease of uncertain origin with increased collagen and fibroblast proliferation with irregular distribution [6]. The pathogenesis of this disease remains uncertain. The high prevalence of monoclonal gammopathy, which presents 


\section{Case Reports in Dermatology}

in up to $80 \%$ of patients, suggests a possible immune response of B-cell to antigenic mucin deposits in the dermis [1].

The treatment of scleromyxedema is not well defined. Various therapeutic agents have been used: high-dose corticosteroids, a variety of immunosuppressive and chemotherapeutic drugs, PUVA and UVA1 phototherapy, plasmapheresis, extracorporeal photopheresis, electron beam therapy, interferon- $\alpha$, retinoids, thalidomide, IVIG, bortezomib, and autologous stem cell transplantation [3].

Dolenc-Voljc et al. [3] reported a case of scleromyxedema without underlying paraproteinemia that was treated with thalidomide for the first 3 months. High-dose IVIG was then added because of partial regression of the disease. Abarzua et al. [6] in 2014 reported a patient without paraproteinemia. Despite treatment with thalidomide, the patient remained stable with maintenance of injuries. In a retrospective multicenter study in France, Le Moigne et al. [7] showed one complete remission (from 8 patients) with thalidomide and another one with dexamethasone. Caudill and Howell [5] explained complete remission of scleromyxedema in a 60-year-old man with IVIG.

In most of the mentioned reports, scleromyxedema was often accompanied by paraproteinemia. We report an unusual case of this disease not associated with monoclonal gammopathy. Scleromyxedema is usually associated with multiple systemic disorders such as gastrointestinal, neurological, cardiac, muscular, renal, pulmonary, and ophthalmological disorders. All of these associations represent events that can cause disability and may be fatal; thus, immediate and aggressive intervention is required [6]. In cases of serious disfiguring and refractory illness, encouraging results have been obtained with the use of IVIG and autologous transplantation of stem cells [8]. Based on lack of monoclonal gammopathy in our patient and no internal involvement, we treated the patient with thalidomide in combination with prednisolone for 3 months. Similar to the aforementioned studies, we observed only a moderate improvement of cutaneous lesions.

\section{Conclusion}

Treatment of scleromyxedema is a challenging process and needs extensive studies to determine effective and first-step regimes. According to moderate response of skin lesions and elimination of the subject, treatment of scleromyxedema is a challenging process and needs extensive studies to determine an effective and first-step regime.

Based on the moderate response of skin lesions and elimination of symptoms, initial treatment with thalidomide and prednisolone may be beneficial. However, adding other agents (e.g., IVIG) may lead to a more robust recovery. Further clinical studies to determine an effective regimen are required.

\section{Statement of Ethics}

The patient's consent to publish this case was obtained.

\section{Disclosure Statement}

This work was not supported by any institution or company. 


\section{Case Reports in Dermatology}

\begin{tabular}{l|l}
\hline Case Rep Dermatol 2016;8:327-332 \\
\hline DOI: 10.1159/000452319 & $\begin{array}{l}\text { C 2016 The Author(s). Published by S. Karger AG, Basel } \\
\text { www.karger.com/cde }\end{array}$ \\
\hline
\end{tabular}

Saniee and Davarnia: Scleromyxedema without Paraproteinemia: Treatment with Thalidomide and Prednisolone

\section{References}

1 Rongioletti F, Rebora A: Updated classification of papular mucinosis, lichen myxedematosus, and scleromyxedema. J Am Acad Dermatol 2001;44:273-281.

2 Breathnach SM: Mucinoses; in Burns T, Breathnach S, Cox N, Griffiths C (eds): Rook's Textbook of Dermatology. Wiley Blackwell, 2010, vol 3, p 22.

-3 Dolenc-Voljc M, Jurcic V, Hocevar A, Tomsic M: Scleromyxedema with subcutaneous nodules: successful treatment with thalidomide and intravenous immunoglobulin. Case Rep Dermatol 2013;5:309-315.

4 Rongioletti F, Rebora A: Mucinoses; in Bolognia JL, Jorizzo JL, Schaffer JV (eds): Dermatology. Elsevier, 2012, vol 1, p 692.

-5 Caudill L, Howell E: Scleromyxedema: a case clinically and histologically responsive to intravenous immunoglobulin. J Clin Aesthet Dermatol 2014;7:45-47.

6 Abarzua AA, Giesen LF, Sandoval MO, Gonzalez SB: Scleromyxedema without paraproteinemia. Int J Dermatol 2014;53:971-974.

-7 Le Moigne M, Mazereeuw-Hautier J, Bonnetblanc JM, et al: Clinical characteristics, outcome of scleromyxoedema: a retrospective multicentre study (in French). Ann Dermatol Venereol 2010;137:782-788.

8 Demarchi M: Scleromyxedema. Dermatol Argent 2007;13:23-36.



Fig. 1. Scleromyxedema. Thickening of the skin of the forehead leading to furrows and folds. 


\section{Case Reports in Dermatology}

\begin{tabular}{l|l}
\hline Case Rep Dermatol 2016;8:327-332 \\
\hline DOI: 10.1159/000452319 & $\begin{array}{l}\text { C } 2016 \text { The Author(s). Published by S. Karger AG, Basel } \\
\text { www.karger.com/cde }\end{array}$ \\
\hline
\end{tabular}

Saniee and Davarnia: Scleromyxedema without Paraproteinemia: Treatment with Thalidomide and Prednisolone



Fig. 2. Scleromyxedema. Numerous firm skin-colored papules on the chest.

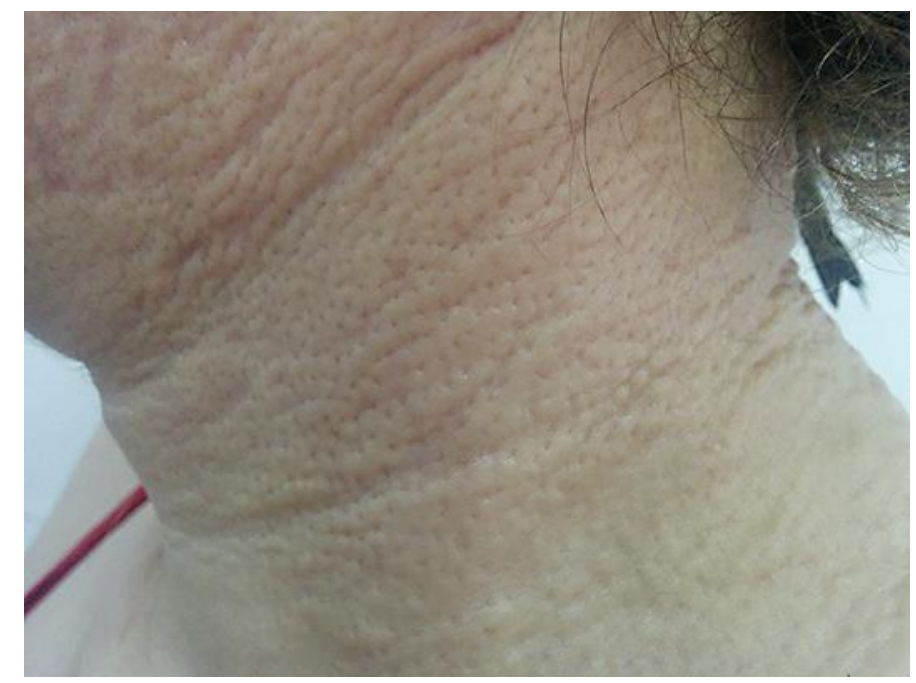

Fig. 3. Scleromyxedema. Thickening of the skin papules in a linear arrangement on the neck. 


\section{Case Reports in

Case Rep Dermatol 2016;8:327-332 DOI: $10.1159 / 000452319$

Saniee and Davarnia: Scleromyxedema without Paraproteinemia: Treatment with Thalidomide and Prednisolone



Fig. 4. Scleromyxedema. Sclerodermoid papules are seen on the arm.



Fig. 5. Pathology. Fibrosis, increased number of fibroblasts, deposits of mucin in the dermis. 